\title{
Perlindungan Hukum Terhadap Kebudayaan Melalui World Heritage Centre UNESCO
}

\author{
Dyah Permata Budi Asri \\ Fakultas Hukum Universitas Janabadra \\ Jln. Timoho II No. 40 Yogyakarta \\ dyahpermata55@gmail.com
}

Received: 15 Mei 2018; Accepted: 12 September 2018; Published: 5 Nopember 2018

DOI: 10.20885/iustum.vol25.iss2.art3

\begin{abstract}
Legal protection for culture is important because Indonesia has a diversity of cultures which serve as valuable assets. The problems of this study were first, why is the arrangement of Traditional Cultural Expressions in DIY needed in order to provide protection? Second, what is the legal protection of traditional cultural expressions according to UNESCO World Heritage Center? This study aimed to find out about the reasons why the protection for TCE is important and the TCE protection according to UNESCO World Heritage Center. This was a normative legal research using both primary and secondary data. The result of this research concludes that Yogyakarta has carried out efforts to protect and maintain culture because this region has a diversity of cultures so there is a possibility that the ownership of these cultures is claimed by other parties. The local government of Yogyakarta has carried out inventory and documentation efforts, but these efforts are not yet optimal. UNESCO through its World Heritage Center has also performed inventory and documentation on Indonesian cultures. Preventive measures through inventory and documentation are needed to prevent Indonesian cultures from being claimed and exploited without permission by other countries. Until the present time, there are 19 (nineteen) Indonesian cultures that have received UNESCO's recognition.
\end{abstract}

Keywords: Traditional cultural expressions; inventory and documentation; legal protection; preventive protection; world heritage centre

\section{Abstrak}

Perlindungan hukum terhadap kebudayaan merupakan hal yang penting dilakukan karena Indonesia memiliki beragam kebudayaan yang merupakan aset berharga. Permasalahan yang diteliti adalah pertama, mengapa pengaturan Ekspresi Budaya Tradisional di DIY diperlukan dalam rangka memberikan perlindungan? Kedua, bagaimanakah perlindungan hukum terhadap ekspresi kebudayaan tradisional menurut World Heritage Centre UNESCO? Tujuan Penelitian ini adalah ingin mengetahui tentang alasan pentingnya perlindungan terhadap EBT dan perlindungan EBT menurut World Heritage Centre UNESCO. Penelitian ini merupakan penelitian yuridis normatif dengan menggunakan data sukender dan data primer sebagai penunjang. Hasil dari penelitian ini menyimpulkan, Pertama, Yogyakarta sudah melaksanakan upaya perlindungan dan pengelolaan kebudayaan, hal ini dilandasi alasan beragamnya kebudayaan di Yogyakarta sehingga berpotensi dilakukan klaim kepemilikan oleh pihak asing. Sudah ada upaya inventarisasi dan dokumentasi kebudayaan yang dilakukan oleh pemerintah daerah di Yogyakarta meski belum optimal. Kedua, UNESCO melalui World Heritage Centre telah melakukan upaya inventarisasi dan dokumentasi terhadap kebudayaan dari Indonesia. Upaya perlindungan preventif dilakukan dengan inventarisasi dan dokumentasi diperlukan untuk mencegah budaya-budaya milik Indonesia, agar tidak diakui dan dimanfaatkan tanpa izin oleh negara lain. Hingga saat ini kebudayaan Indonesia yang telah diakui UNESCO ada 19

Kata-kata Kunci: Ekspresi Budaya Tradisional; inventarisasi dan dokumentasi; perlindungan hukum, perlindungan preventif, world heritage centre 


\section{Pendahuluan}

Pembahasan tentang perlunya perlindungan bagi kebudayaan telah menjadi isu penting dewasa ini, hal ini disebabkan karena maraknya klaim terhadap kebudayaan-kebudayaan Indonesia yang diklaim kepemilikannya oleh negara asing akhir-akhir ini. Isu mengenai perlindungan terhadap kebudayaan Indonesia mulai menjadi "panas" kurang lebih dalam beberapa tahun terakhir, ketika persoalan tuduhan klaim atas tari Reog Ponorogo dan Pendet oleh Malaysia, dipublikasikan secara luas di media massa. Namun demikian, sebenarnya isu ini telah menjadi salah satu bahan perdebatan di tingkat internasional sejak 2001, ketika sidang pertama Intergovernmental Committee on Intellectual Property and Genetic Resources, Traditional Knowledge and Folklore (IGC GRTKF) diselenggarakan di markas besar WIPO di Jenewa, Swiss. ${ }^{1}$ Bahkan, sebenarnya substansi mengenai pengetahuan tradisional dan ekspresi budaya tradisional telah menjadi bahan perdebatan sejak 1967, ketika Bern Convention for the Protection of Literary and Artistic Works menambahkan Pasal 15.4, yang isinya adalah menyatakan bahwa karya yang belum dipublikasikan dan yang tidak dikenal penciptanya, dapat dilindungi sebagai hak cipta jika diduga si pencipta adalah warga negara pihak pada konvensi tersebut. Di samping itu, negara pihak pada konvensi ini diminta untuk menunjuk otoritas yang berwenang untuk memberikan perlindungan.

Salah satu kasus pelanggaran kepemilikan kebudayaan yang terjadi adalah kasus klaim kebudayaan Indonesia oleh Malaysia. Dalam sebuah iklan di Discovery Channel dalam Enigmatic Malaysia, ditayangkan tari pendet, wayang, dan Reog Ponorogo yang merupakan kekayaan tradisional Malaysia.2 ${ }^{2}$ Padahal, telah diketahui secara umum bahwa ketiganya merupakan ekspresi budaya tradisional Indonesia. Pemanfaatan ekspresi budaya tradisional oleh pihak asing juga terjadi di beberapa negara, conothnya, di Las Vegas, USA, ada sebuah hotel yang menggunakan desain dengan ciri khas timur tengah, khususnya Mesir, lengkap dengan merchandise yang mengindikasikan geografi tertentu. Juga di Seattle, USA,

1 Basuki Antariksa, Peluang dan Tantangan Perlindungan Pengetahuan Tradisional dan Ekspresi Budaya TradisionalMakalah yang disampaikan dalam acara Konsinyering Pencatatan Warisan Budaya Takbenda (WBTB) Indonesia, yang diselenggarakan oleh Direktorat Jenderal Nilai Budaya, Seni dan Film - Kementerian Kebudayaan dan Pariwisata, di Jakarta, tanggal 7 Oktober 2011, hlm. 1.

2 Malaysia Sudah Tujuh Kali Mengklaim Budaya Indonesia, https:// nasional.tempo.co/read/411954/malaysia-sudah-tujuh-kali-mengklaim-budaya-ri, diakses 27 Mei 2018 
terdapat toko yang menjual produk-produk dengan ciri khas tertentu, seperti boomerang, topi-topi Indian, dan produk-produk dengan desain yang bercirikan karya seni dari suku-suku bangsa tertentu di berbagai belahan dunia. ${ }^{3}$

Kebudayaan merupakan salah satu jenis ciptaan yang dihasilkan oleh kemampuan intelektual manusia, dalam hal ini masyarakat hukum adat sebagai pencipta, atau pihak yang memelihara dan menurunkan kebudayaan tersebut dari generasi ke generasi berikutnya. Oleh karena itu, meski kebudayaan merupakan hasil olah pikir dari kemampuan intelektual manusia namun perlu dibedakan dengan karya intelektual yang lainnya. Perbedaannya adalah bahwa kebudayaan merupakan hasil karya intelektual masyarakat secara bersama/kolektif/komunal, sedangkan karya intelektual pada umumnya lebih menitik beratkan pada karya yang lahir dari kemampuan intelektual individu/ perorangan.

Sekalipun terdapat perbedaan konsep antara kebudayaan sebagai milik masyarakat komunal dengan karya cipta lainnya yang bersifat individual, namun tentang kebudayaan di Indonesia diatur dalam Undang-Undang Hak Cipta Nomor 28 Tahun 2014 tentang Hak Cipta, khususnya dalam Bab V tentang Ekspresi Budaya Tradisional dan Ciptaan yang Dilindungi, Pasal 38, yang menyebut kebudayaan sebagai ekspresi budaya tradisional. Terhadap ekspresi budaya tradisional tersebut negara diberikan kewajiban yang dimuat dalam Pasal 38 ayat (2) secara eksplisit.

Potensi terhadap pelanggaran klaim budaya di Yogyakarta akan selalu ada, dikarenakan daya tarik Yogyakarta ada pada wisata budayanya, sekalipun hingga saat ini belum ada kasus terjadinya kliam kebudayaan dari Yogyakarta oleh negara lain. Oleh karena itu, diperlukan upaya untuk proteksi secara preventif terhadap pemeliharaan budaya di Yogyakarta.

Ekspresi budaya tradisional ada dua yaitu kebudayaan yang berwujud (tangible culture) dan kebudayaan tak benda/tidak berwujud (intangible culture). ${ }^{4}$ Untuk penelitian ini lebih difokuskan pada kebudayaan tak benda seperti nilainilai budaya, upacara adat dan legenda, hikayat dan lain sebagainya.

${ }^{3}$ https://newsplus.antvklik.com/news/kebudayaan-indonesia-diklaim-malaysia/0, diakses tanggal 7 Mei

4 Asri, D. P. B., "Implementasi Pasal 38 ayat (1) Undang-Undang Nomor 28 Tahun 2014 terhadap Ekspresi Budaya Tradisional di Kabupaten Sleman”, Jurnal Hukum Ius Quia Iustum, Vol. 23 No. 4 Oktober 2016, hlm. 618. 
Dalam Undang-Undang Hak Cipta Nomor 28 Tahun 2014 dimana konsep perlindungan yang ditawarkan oleh undang-undang tersebut adalah individual liberalisme. Sedangkan ekspresi budaya tradisional yang diatur dalam undangundang tersebut menganut asas komunal kebersamaan, yang tidak cocok dengan ruh dari undang-undang tersebut. Oleh karena itu, sudah bisa dipastikan, penerapannya menjadi kabur, dimana aspek perlindungannya dari ekspresi budaya tradisional berbeda dengan jenis hak cipta.

Pemberian perlindungan bagi ekspresi budaya tradisional menjadi penting ketika dihadapkan pada karakteristik dan keunikan yang dimilikinya dan juga berperan positif memberikan dukungan kepada komunitas masyarakat hukum adat selaku pemilik dan pengemban kebudayaan tersebut untuk melestarikan tradisinya. Agar kepemilikannya tidak diakui tanpa izin oleh negara lain. Oleh sebab itu, kekayaan budaya tersebut perlu memperoleh perlindungan hukum. Apalagi diketahui jelas, bahwa semua kekayaan yang berbasis budaya tradisional mempunyai nilai ekonomi yang sangat tinggi.

\section{Rumusan Masalah}

Berdasarkan uraian di atas, permasalahan dalam penelitian ini adalah, pertama, mengapa pengaturan ekspresi budaya tradisional di DIY diperlukan dalam rangka memberikan perlindungan? Kedua, bagaimanakah perlindungan hukum terhadap ekspresi kebudayaan tradisional menurut World Heritage Centre UNESCO?

\section{Tujuan Penelitian}

Tujuan penelitian ini untuk, pertama, mendeskripsikan pentingnya pengaturan tentang ekspresi budaya tradisional di DIY. Kedua, mengetahui perlindungan hukum terhadap ekspresi budaya tradisional menurut World Heritage Centre UNESCO.

\section{Metode Penelitian}

Penelitian ini merupakan penelitian yuridis normatif. Penelitian yuridis normatif ini dilakukan dengan cara menelaah dan meng-interpretasikan hal-hal yang bersifat teoritis yang menyangkut asas, konsepsi, doktrin dan norma hukum 
yang berkaitan dengan pengaturan ekspresi budaya tradisional dalam peraturan hak kekayaan intelektual. Sumber data yang dipakai dalam penelitian ini menggunakan data sekunder. Namun, untuk memperkuat data sekunder, penulis juga menggunakan data primer sebagai penunjang data sekunder seperti halnya observasi dan wawancara. Alat dan cara penelitian dilakukan melalui studi dokumen dan analisisnya secara deskriptif kualitatif.

\section{Hasil Penelitian dan Pembahasan}

\section{Alasan yang Mendasari Pentingnya Perlindungan Ekspresi Budaya Tradisional di DIY}

Ekspresi budaya tradisional (traditional cultural expressions/expressions of folklore) sebagai salah satu bentuk dari kekayaan intelektual tradisional, memiliki potensi ekonomi yang menjanjikan terutama terkait dengan industri pariwisata dan industri ekonomi kreatif di Indonesia. Perlindungan kebudayaan di Yogyakarta menuntut perhatian pemerintah dan masyarakat. Yogyakarta kecuali sebagai "kota pelajar" juga menjadi daerah tujuan wisata penting di Indonesia yang bertumpu pada sumberdaya ekonomi kreatif (cultural economic) yaitu kebudayaan, terutama pada berbagai kesenian seperti perayaan adat dan pesta rakyat.

Di Bali misalnya, yang hampir semuanya berbasis ekspresi budaya tradisional dan mempunyai sumbangan yang sangat besar sebagai sumber pendapatan ekonomi daerah serta menjadikan Bali dikenal seluruh dunia. Di bidang industri ekonomi kreatif terutama produk kerajinan berbasis ekspresi budaya tradisional seperti, kerajinan batik, ukir kayu, ukir tembaga, perak adalah produk mempunyai sumbangan yang cukup besar untuk menyumbang devisa negara. ${ }^{5}$

Arti penting terhadap perlindungan kebudayaan tercerrmin dalam berbagai kebijakan terkait kebudayaan di Yogyakarta dalam rangka perlindungannya secara terintegrasi melalui melalui kegiatan inventarisasi dan pendokumentasian kebudayaan yang ada di Yogyakarta. Seperti yang telah dilakukan oleh Dinas

5 Kholis Roisah, "Perlindungan Ekspresi Budaya Tradiosional dalam Sistem Hukum Hak Kekayaan Intelektual" Jurnal Masalab-Masalab Hukum, Fakultas Hukum Universitas Diponegoro, Jilid 43 Nomor 3 (Juli 2014), hlm. 373 
Kebudayaan Propinsi Daerah Istimewa Yogyakarta sejak 2013, telah berupaya melakukan inventarisasi sejumlah kebudayaan di Yogyakarta. Tercatat ada 22 karya budaya di Yogyakarta yang telah ditetapkan sebagai warisan budaya tak benda Indonesia. Budaya tersebut adalah6: Wayang Beber (2013); Wayang Wong Mataraman (2013); Wayang Kancil (2013); Sekaten (2014); Pawukon (2014); Bedhaya Semang (2014); Gamelan Gaya Yogyakarta (2014); Kertas Daluang (2014); Mubeng Beteng (2015); Saparan Gamping/ Bekakak (2015); Gudeg (2015); Joglo Yogyakarta (2015); Kerajinan Gerabah Kasongan (2015); Surau Mbah Demang (2016); Tawur Kesanga (2016); Labuhan Keraton (2016); Jathilan Yogyakarta (2016); Langendriyo (2016); Tari Angguk (2016); Langen Mandra Wanara (2016); Bakpia Yogyakarta (2016); dan Batik Lurik Yogyakarta (2016).

Selain inventarisasi kebudayaan di Yogyakarta, selama ini Dinas Kebudayaan DI Yogyakarta, juga telah berupaya untuk memelihara keberadaan sejumlah kebudayaan tersebut dengan cara memberikan reward secara rutin kepada pelaku budaya melalui penghargaan anugerah budaya baik kategori seniman, budayawan kelompok maupun lembaga adat, dengan memberikan insentif berupa uang penghargaan sebesar Rp. 25.000.000,00 per orang/lembaga. ${ }^{7}$

Berbagai kenyataan yang terjadi atas peristiwa pemanfaatan ekspresi budaya tradisional milik masyarakat adat tertentu di tingkat internasional, menjadi latar belakang pentingnya sistem hukum yang dapat melindungi hak dan kepentingan masyarakat hukum adat, atas pemanfaatan secara tidak sebenarnya / penyalahgunaan (misappropriation) terhadap berbagai bentuk budaya yang dimilikinya. 8

Di dalam Undang-Undang Nomor 28 Tahun 2014 tentang Hak Cipta, mengatur mengenai ekspresi budaya tradisional, khususnya dalam Pasal 38 ayat (1, 2, 3 dan 4) Undang-Undang Hak Cipta, secara berturut-turut akan disampaikan sebagai berikut :

(1)Hak cipta atas ekspresi budaya tradisional dipegang oleh negara

\footnotetext{
${ }^{6}$ Wawancara dengan Ibu Dian Laksmi, Kepala Bidang Pelestarian Warisan dan Nilai Budaya Dinas Kebudayaan DIY, pada tanggal 19 April 2017

${ }^{7}$ Ibid

8 Permata, D., "Perlindungan Dan Pengelolaan Budaya Lokal Di Kota Yogyakarta". E-Journal Kajian Hukum, Fakultas Hukum Universitas Janabadra Vol. 1 No. 1 Tahun 2016, hlm. 7
} 
(2)Negara wajib menginventarisasi, menjaga, dan memelihara ekspresi budaya tradisional sebagaimana dimaksud pada ayat (1).

(3)Penggunaan ekspresi budaya tradisional sebagaimana dimaksud pada ayat (1) harus memperhatikan nilai-nilai yang hidup dalam masyarakat pengembannya.

(4)Ketentuan lebih lanjut mengenai hak cipta yang dipegang oleh negara atas ekspresi budaya tradisional sebagaimana dimaksud pada ayat (1) diatur dengan Peraturan Pemerintah.

Agar suatu ekspresi memenuhi syarat traditional cultural expression, ekspresi tersebut harus menunjukkan adanya kegiatan intelektual individu maupun kolektif yang merupakan ciri dari identitas dan warisan suatu komunitas, dan telah dipelihara, dikembangkan atau digunakan oleh komunitas tersebut, atau oleh perorangan yang memiliki hak atau tanggung jawab untuk melakukannya sesuai dengan hukum dan praktik adat/kebiasaan dalam komunitas tersebut. ${ }^{9}$

Konsep-konsep cakupan perlindungan ekspresi budaya tradisional sangat erat kaitannya dengan daerah sebagai "pengemban" budaya tradisional, sehingga pemerintah daerah, baik provinsi maupun kabupaten/kota memegang tugas dan fungsi penting dalam perlindungan dan pemanfaatannya.

Negara sebagai otoritas tertinggi, dan pemerintah daerah sebagai representasi negara dalam perlindungan dan pengaturan ekspresi budaya tradisional dapat mencegah adanya monopoli atau komersialisasi serta tindakan yang merusak atau pemanfaatan komersialisasi oleh pihak asing tanpa seizin negara sebagai pemegang hak cipta. Walaupun demikian implementasi ketentuan tersebut apabila diterapkan terhadap perlindungan ekspresi budaya tradisional kemungkinan akan mengalami kesulitan karena tidak memberikan informasi tentang badan yang ditunjuk, fungsi dan tanggung jawabnya.

Di satu sisi pada kenyataannya belum ada usaha dari negara dalam rangka melindungi karya-karya tradisional yang dieksploitasi oleh negara lain atau pihak lain sebagai pihak asing yang tidak memiliki hak untuk mengeksploitasi. ${ }^{10}$

Ekspresi budaya tradisional perlu mendapatkan perlindungan hukum, dilatarbelakangi beberapa alasan, antara lain :

\footnotetext{
${ }_{9}^{9}$ Purba Afrillya,Andrian Krisnawati dan Gazalba Shaleh, TRIP's-WTO dan Hukum HKI Indonesia, Jakarta; Rineka Cipta, 2005, hlm. 103

10 Asri, D. P. B., "Model Kebijakan Strategis Terhadap Pelestarian Kebudayaan Lokal "Merti Code" Sebagai Aset Daerah Untuk Meningkatkan Sektor Pariwisata Berbasis Budaya”. Jurnal Jarlit, 10, 2017, hlm. 146.
} 
1) Munculnya kesadaran negara-negara berkembang untuk melindungi kekayaan intelektualnya tersebut, termasuk dari kepunahannya, berdasarkan WIPO Fact Finding Missions;

2) Penggunaan yang menyimpang oleh negara-negara barat dengan mengambil dan menggunakan pengetahuan tersebut untuk kepentingan dirinya sendiri melalui klaim hak kekayaan intelektual. Dalam konteks ini telah terjadi penyimpangan penggunaan Pengetahuan Tradisionalnya dari konsep awalnya sebagai cultural heritage menjadi Hak Kekayaan Intelektual.

Sistem hukum hak kekayaan intelektual atas ekspresi budaya tradisional yang telah ditetapkan dalam Undang-Undang Nomor 28 Tahun 2014 mengenai Hak Cipta belum mencukupi kebutuhan masyarakat akan perlunya perlindungan terhadap ekspresi budaya tradisional. Perbedaan karakter antara hak kekayaan intelektual dan ekspresi budaya tradisional membuat sistem hukum kekayaan intelektual kita tak cukup mampu melindungi secara utuh ekspresi budaya tradisional. secara karakter, walaupun sama-sama bersumber dari kreativitas intelektual manusia, di antara keduanya terdapat perbedaan mendasar.

Bila dilihat dari akar budaya, hak kekayaan intelektual tidak mempunyai akar dalam kebudayaan bangsa Indonesia dan juga tidak terdapat dalam sistem hukum adat. ${ }^{11}$ Masyarakat adat pada umumnya tidak mengenal konsep hak kekayaan intelektual. Demikian juga konsep yang menyangkut perlindungan hak cipta bukan merupakan ide yang dimiliki bangsa Indonesia. ${ }^{12}$ Masyarakat asli Indonesia pada umumnya tidak mengenal konsep yang bersifat abstrak termasuk konsep hak atas Kekayaan Intelektual, masyarakat adat Indonesia tidak pernah membayangkan bahwa buah pikiran (intellectual creation) adalah kekayaan (property). ${ }^{13}$

Permasalahan yang mendasar adalah bahwa nilai-nilai budaya masyarakat setempat tidak mengenal kepemilikan individu terhadap suatu karya cipta dalam bidang ilmu pengetahuan, sastra dan seni. Keadaan ini tampak jelas dalam penghargaan atas kreativitas dan karya seni dalam masyarakat tradisional. ${ }^{14}$

11 Hukum Indonesia asli yang tidak tertulis dalam bentuk perundang-undangan yang disana sini mengandung unsur agama, lihat Hilman Hadikusuma, Pengantar Ilmu Hukum, Mandar Maju, Bandung, 1992, hlm. 32.

12 OK Saidin, Aspek Hukum Hak Kekayaan Intelektual, RajaGrafindo Persada, Jakarta, 1995, hlm. 27

13 Agus Sarjono, Membumikan HKI di Indonesia, Nuasa Aulia, Bandung, 2009, hlm. 20

14 Budi Agus Riswandi, Syamsudin, Hak Kekayaan Intelektual dan Budaya Hukum, Raja Grafindo Persada, Jakarta, 2005, hlm. 204 
Perlindungan yang dimaksud adalah segala bentuk upaya melindungi Ekspresi Budaya Tradisional terhadap pemanfaatan yang dilakukan tanpa hak dan melanggar kepatutan. Perlindungan ekspresi budaya tradisional sebagai bagian pengetahuan tradisional ini sangat penting, setidaknya karena 3 alasan, yaitu : 15

a. Adanya potensi keuntungan ekonomis yang dihasilkan dari pemanfaatan pengetahuan tradisional,

b. Keadilan dalam sistem perdagangan dunia, dan

c. Perlunya perlindungan hak masyarakat lokal.

Yogyakarta sebagai daerah istimewa berdasarkan Undang-undang Keistimewaan Yogyakarta dan Peraturan Daerah Istimewa DI Yogyakarta (Perdais) memiliki kewenangan wajib terkait dengan urusan kebudayaan sesuai yang diatur dalam Perdais tersebut. Ruang lingkup pengaturan kewenangan dalam urusan keistimewaan meliputi: ${ }^{16}$ tata cara pengisian jabatan, kedudukan, tugas dan wewenang Gubernur dan Wakil Gubernur; kelembagaan Pemerintah Daerah; kebudayaan; pertanahan; dan tata ruang.

Kebijakan penyelenggaraan kewenangan kebudayaan diselenggarakan untuk melindungi, mengembangkan dan memanfaatkan hasil cipta, rasa, karsa dan karya berupa:17 nilai-nilai; pengetahuan; norma; adat istiadat; benda; seni; dan tradisi luhur yang mengakar dalam masyarakat DIY.

Pelindungan, pengembangan, dan pemanfaatan sebagaimana dimaksud, dapat dilakukan melalui: ${ }^{18}$ inventarisasi; pendokumentasian; penyelamatan; penggalian; penelitian dan pengembangan; pengayaan; pendidikan; pelatihan; penyajian; penyebarluasan; revitalisasi; dekonstruksi dan rekontruksi; penyaringan; dan rekayasa

Selain diatur dalam Perdais tersebut, kebudayaan tradisional di Yogyakarta juga diatur dalam Peraturan Daerah Provinsi Daerah Istimewa Yogyakarta Nomor 4 Tahun 2011 tentang Tata Nilai Budaya Yogyakarta. Yang dimaksud tata

15 Agus Sardjono, Hak Kekayaan Intelektual dan Pengetahuan Tradisional, Alumni, Bandung, 2006, hlm. 2-3

16 Pasal 4 Peraturan Daerah Istimewa DI Yogyakarta Nomor 1 Tahun Tahun 2013 tentang Kewenangan Dalam Urusan Keistimewaan Daerah Istimewa Yogyakarta

${ }^{17}$ Ibid., Pasal 35 ayat (1).

18 Ibid., Pasal 35 ayat (2). 
nilai budaya sebagaimana ketentuan dalam Perda tersebut adalah merupakan kekayaan daerah tidak berwujud (intangible) yang tak ternilai sehingga perlu dilestarikan, dikembangkan, dan dilindungi dengan peraturan daerah.

Saat ini Pemerintah Daerah di DI Yogyakarta telah memiliki regulasi yang akan mengatur mengenai budaya tradisional yang berasal dari DI Yogyakarta. Pengaturan tersebut adalah Peraturan Gubernur Daerah Istimewa Yogyakarta Nomor 21 Tahun 2017 tentang Penggunaan Merek Jogjamark, 100\% Jogja dan Jogja Tradition Sebagai Co Branding Produk Daerah.

Co Branding yang meliputi Jogjamark, 100\% Jogja dan Jogja Tradition telah didaftarkan ke Direktorat Jenderal Kekayaan Intelektual Kementerian Hukum dan HAM RI. Pengajuan co-branding dilakukan Pemda DI Yogyakarta atas nama Gubernur DI Yogyakarta. Instansi yang memprakarsai fasilititasi Co Branding di Yogyakarta adalah Dinas Perindustrian dan Perdagangan DI Yogyakarta melalui Unit Pelayanan Teknis (UPT) Pelayanan Bisnis dan Pengelolaan Kekayaan Intelektual. ${ }^{19}$

Dalam Peraturan Gubernur Daerah Istimewa Yogyakarta Nomor 21 Tahun 2017 tentang Penggunaan Merek Jogjamark, 100\% Jogja dan Jogja Tradition sebagai Co Branding Produk Daerah, disebutkan definisi dari Jogja Tradition dalam Pasal 1 Butir 4 yaitu adalah "Tanda yang menunjukan identitas dan ciri pengetahuan tradisional dan/atau ekspresi budaya tradisional khas Daerah Istimewa Yogyakarta yang terdiri dari bentuk gunungan wayang dan kata Jogjatradition. Sedangkan dalam butir 7 disebutkan mengenai definisi ekspresi budaya tradisional yaitu karya intelektual dalam bidang seni yang mengandung unsur karakteristik warisan budaya tradisional yang dihasilkan, dikembangkan, dan dipelihara oleh komunitas atau masyarakat tertentu dan menjadi ciri khas Daerah Istimewa Yogyakarta.

Keberadaan Peraturan Gubernur tersebut setidaknya telah memberikan landasan hukum terhadap pentingnya perlindungan dan pengelolaan warisan budaya di Yogyakarta, sebagaimana diamanahkan oleh Undang-undang Hak

19 Wawancara dengan Bapak Drs. Bambang Wahyu Indriya Kepala Balai Pelayanan Bisnis dan Pengelolaan Kekayaan Intelektual Disperindag DIY, pada tanggal 10 April 2017 
Cipta khususnya dalam Pasal 38 ayat (2), meskipun belum optimal dan menyeluruh.

Dalam Perdais maupun Perda yang mengatur mengenai budaya di Yogyakarta, sistem perlindungan sudah diatur secara jelas, yaitu dengan melakukan inventarisasi dan pendokumentasian terhadap berbagai macam budaya yang ada di Yogyakarta. Meskipun secara teknis aturan-aturan tersebut belum menyebut lengkap mekanisme dan petunjuk teknisnya dalam melakukan kegiatan inventarisasi dan dokumentasi tersebut.

Sudah sewajarnya Yogyakarta yang sarat dengan nilai-nilai kebudayaan luhur dapat dilindungi dan dilestarikan, tentu tanpa melupakan adanya dinamika manusia pendukungnya. Arti pentingnya perlindungan terhadap kebudayaan di Yogyakarta telah tercermin dalam beberapa kebijakan yang dikeluarkan Pemerintah Daerah di Yogyakarta. Pelaksanaan perlindungan kebudayaan di Yogyakarta dilakukan dengan melakukan kegiatan preventif dalam rangka menjaga kebudayaan tersebut dari potensi klaim kepemilikan, yaitu dengan melakukan inventarisasi dan dokumentasi, seperti yang diamanatkan dalam Pasal 38 ayat (1) Undang-Undang Nomor 28 Tahun 2014 tentang Hak Cipta.

\section{Perlindungan Hukum Terhadap Ekspresi Budaya Tradisional Menurut World Heritage Centre UNESCO}

Sebelum membahas mengenai klaim kepemilikan kebudayaan, maka akan dijelaskan terlebih dahulu mengenai makna perlindungan hukum. Perlindungan hukum adalah memberikan pengayoman kepada hak asasi manusia yang dirugikan orang lain dan perlindungan tersebut diberikan kepada masyarakat agar mereka dapat menikmati semua hak-hak yang diberikan oleh hukum atau dengan kata lain perlindungan hukum adalah berbagai upaya hukum yang harus diberikan oleh aparat penegak hukum untuk memberikan rasa aman, baik secara pikiran maupun fisik dari gangguan dan berbagai ancaman dari pihak manapun. ${ }^{20}$

${ }^{20}$ Satjipto Rahardjo. Hukum Dalam Perspektif Sejarah dan Perubahan Sosial, Dalam Pembangunan Hukum Dalam Perspektif Politik. Hukum Nasional, Editor Artidjo Alkostar, Rajawali, Jakarta, 1986, hlm. 74 
Menurut pendapat Phillipus M. Hadjon bahwa perlindungan hukum bagi rakyat sebagai tindakan pemerintah yang bersifat preventif dan represif. Perlindungan hukum yang preventif bertujuan untuk mencegah terjadinya sengketa, yang mengarahkan tindakan pemerintah bersikap hati-hati dalam pengambilan keputusan berdasarkan diskresi, dan perlindungan yang represif bertujuan untuk menyelesaikan terjadinya sengketa, termasuk penanganannya di lembaga peradilan. ${ }^{21}$

Pada kasus komersialisasi ekspresi budaya tradisional, sebagaimana dalam sengketa perajin mebel ukir Jepara dengan pengusaha asing PT Harrison \& GrillJava yang justru melakukan somasi, melarang perajin lokal. ${ }^{22}$ Lebih tragis lagi beberapa motif tradisional ukir perak Bali didaftarkan oleh warga asing, baik yang tinggal di Indonesia maupun di luar negeri, sebagaimana John Hardy yang menggugat perajin lokal Indonesia. Di lain pihak, beberapa kekayaan intelektual dan budaya tradisional Indonesia telah diakui sebagai milik bangsa lain seperti Tari Pendet, Wayang, dan Reog Ponorogo yang di klaim merupakan kekayaan tradisional Malaysia. ${ }^{23}$ Demikian juga naskah kuno masyarakat adat Sulawesi Selatan dan Sulawesi Tenggara telah dimiliki dan digitalisasi oleh Malaysia. ${ }^{24}$

Saat Malaysia menggunakan atau menampilkan beberapa kebudayaan Indonesia, seperti Angklung, Reog, lagu Rasa Sayange, dan sebagainya dalam iklan pariwisatanya, hal ini menjadi permasalahan tersendiri bagi Indonesia, karena pemanfaatan terhadap budaya-budaya Indonesia tersebut jelas untuk kepentingan komersiil Malaysia yaitu promosi pariwisata Malaysia. Artinya Malaysia memanfaatkan secara ekonomi terhadap kebudayaan-kebudayaan Indonesia secara tanpa ijin, berarti dapat diasumsikan melakukan pelanggaran hak kekayaan intelektual di bidang ekspresi budaya tradisional.

Kecenderungan masyarakat dunia saat ini menyebabkan eksplorasi dan eksploitasi terhadap kekayaan masyarakat asli/tradisional semakin meningkat

${ }^{21}$ Phillipus M. Hadjon, Perlindungan Hukum bagi Rakyat Indonesia, PT. Bina Ilmu, Surabaya, 1987, hlm. 29.

22 Eriesta Mauliana, Eksistensi Pendaftaran Ciptaan Ditinjau Dari Undang-Undang No. 19 Tabun 2002 tentang Hak Cipta (Studi Kasus Putusan No. 02/HAKI/C/2007/PN Niaga Semarang, Tesis. Program Pasca Sarjana Magister Kenotariatan, Universitas Diponegoro Tahun 2010, hlm. 1-2

${ }^{23}$ Badan Penelitian dan Pengembangan HAM Kementerian Hukum dan HAM RI, Perlindungan Kekayaan Intelektual Atas Pengetahuan Tradisional dan Ekpresi Budaya Tradisional Masyarakat Adat, Alumni, Bandung, 2013, hlm. 3 April.

${ }^{24} \mathrm{http}$ ///www.pusakaindonesia.org/kekayaan-budaya-indonesia-dan-klaim-negaralain/akses tanggal 28 
karena masyarakat asli/tradisional selama ini memang dikenal mempunyai kearifan tersendiri sehingga mereka memiliki sejumlah kekayaan intelektual yang sangat "bersahabat" dengan alam. Namun, karena lemahnya perlindungan hukum terhadap kekayaan intelektual masyarakat asli tradisional ini, maka yang kebanyakan terjadi justru adalah eksplorasi dan eksploitasi yang tidak sah oleh pihak asing. 25

Hingga saat ini, kesepakatan hukum internasional mengenai hak kekayaan intelektual sebagai upaya perlindungan hak kekayaan intelektual atas warisan budaya masih belum ada. Untuk sementara ini, baru ada sebuah Forum Genetic Resources Traditional Knowledge and Folklore (GRTKF) di Jenewa, Swiss 2009 ini, yang bertujuan mencapai kompromi perlindungan hak kekayaan intelektual berupa hak cipta atas pengetahuan dan ekspresi budaya tradisional yang berkembang di setiap negara, setidaknya perlindungan hukum atas hak cipta ini bisa dicapai pada 2011. Namun, traktat yang akan dirumuskan ini berisiko ditolak oleh banyak negara dan banyak pihak, dengan alasan bahwa warisan budaya berupa pengetahuan dan ekspresi budaya tradisional merupakan karya komunal yang tidak dapat diinvidualisasikan dan memiliki hak cipta.

Sebenarnya dalam konteks hukum Internasional, lembaga PBB dapat memberikan tujuan untuk upaya perdamaian, terutama dalam bidang sengketa kebudayaan tersebut. Oleh karena itu PBB memiliki lembaga yang memiliki fungsi untuk pencegahan sebelum konflik tersebut terjadi. Yaitu UNESCO dengan World Heritage Centre, yang mendokumentasikan dan mengakui sejumlah kebudayaan di seluruh dunia sebagai warisan budaya dunia.

Hal tersebut apabila dilihat dari tujuannya, sesuai dengan amanat yang dinyatakan dalam Pasal 1 Piagam PBB, salah satu tujuannya adalah untuk mempertahankan perdamaian dan keamanan internasional. Tujuan tersebut sangat terkait erat dengan upaya penyelesian sengketa secara damai..26 Sehingga dengan adanya upaya dari PBB melalui organ UNESCO dapat mencegah terjadinya konflik antar negara dalam hal klaim kebudayaan. Sebagaimana telah

\footnotetext{
25 Angelina P. Tololiu, "Perlindungan Hukum Terhadap Kain Bentenan Sebagai Ekspresi Budaya Tradisional Sulawesi Utara” Jurnal Hukum Unsrat, Fakultas Hukum Universitas Sam Ratulangi, Vol.II/No.2/Januari-Maret /2014 Edisi Khusus, hlm. 9

${ }^{26}$ Jawahir Thontowi dan Pranoto Iskandar, Hukum Internasional Kontemporer, (Bandung: PT. Refika Aditama, 2006), hlm. 237
} 
dikemukakan di atas, keterlibatan berbagai pihak secara terkoordinasi dan intensif sangat diperlukan untuk menjamin terlaksananya sistem hak kekayaan intelektual yang diharapkan.

Terhadap perlindungan kekayaan budaya tradisional khususnya yang tidak berwujud juga telah disepakati oleh UNESCO sejak 2001 dengan mengadakan survei yang melibatkan berbagai negara dan organisasi internasional untuk mencapai kesepakatan mengenai cakupan World Intangible Cultural Heritage dan diresmikan 2003 dalam bentuk Konvensi yaitu Convention for The Safeguarding of The Intangible Cultural Heritage.

Beberapa konvensi UNESCO untuk melindungi warisan budaya tidak berwujud antara lain:27

1. Konvensi Hak Cipta Dunia (Universal Copyright Convention) 1952, revisi 1971.

2. Konvensi Perlindungan Warisan Budaya Tidak Benda (Convention for Safeguarding of The Intangible Cultural Haritage) 2003.

3. Konvensi Mengenai Proteksi dan Promosi Keanekaragaman Ekspresi Budaya (Convention on The Protection of The Diversity of Cultural Expressions) 2005.

Dengan meratifikasi berbagai konvensi dan protokol tingkat internasional, Indonesia memiliki konsekuensi dan tanggung jawab yang tidak ringan. Berbagai kebijakan di level nasional terkait dengan bidang kebudayaan, mendorong pemerintah untuk melakukan komitmen melindungi dan mempromosikan keanekaragaman ekspresi budaya, dimana Indonesia diakui oleh dunia internasional memiliki banyak warisan budaya dunia.

UNESCO, telah mengakui 981 situs berdasarkan data UNESCO 2015, sedangkan 2016 ini jumlah situs dunia UNESCO bertambah 21 situs, melalui The United Nations Educational, Scientific and Cultural Organization (UNESCO) of $40^{\text {th }}$ Session of the Committee, sehingga total 1.002 situs di dunia menjadi warisan budaya (The World Heritage), termasuk 14 warisan diantaranya milik Indonesia yang dikelompokkan dalam tiga kategori berbeda, yaitu warisan alam, cagar alam atau situs, dan karya tak benda.

Berikut ini merupakan warisan-warisan berupa cagar budaya yang diakui UNESCO, yakni Kompleks Candi Borobudur (1991), Kompleks Candi Prambanan

\footnotetext{
${ }^{27}$ http://portal.unesco.org/en/ev.phpURL_ID=13649\&URL_DO=DO_TOPIC\&URL_SECTION=471.html, diakses tanggal 20 November 2016
} 
(1991), Situs Manusia Purba Sangiran (1996), Subak sebagi Lanskap Budaya Bali (2012). Selanjutnya, warisan budaya tak benda (intangible culture), yakni wayang (2003), keris (2005), batik (2009), angklung (2010), Tari Saman (2011), Noken (2012), Gamelan (2014), Sekaten (2014), Lumpia (2014) dan Tiga Genre Tradisi Tari Bali (2015). Sedangkan warisan alam dunia, yakni Taman Nasional Ujung Kulon di Banten (1991), Taman Nasional Komodo di NTT (1991), Taman Nasional Lorentz di Papua (1999), Hutan hujan Tropis Sumatera (2004).28

Untuk mendapatkan pengakuan dunia atas warisan budaya nasional, Indonesia harus mengikuti tahapan dan format yang ditentukan UNESCO. Tahap pertama, cabang budaya tersebut harus terdaftar sebagai warisan budaya nasional. Setelah itu, baru bisa masuk ke tahap berikutnya untuk mendapat pengakuan dunia. Setelah pencatatan sebagai warisan budaya nasional, kemudian akan diusulkan kepada warisan budaya dunia. ${ }^{29}$

Pencatatan warisan budaya nasional dilakukan oleh Balai Pelestarian Nilai Budaya dibawah Kementerian Pendidikan dan Kebudayaan Direktorat Jenderal Kebudayaan, dengan melalui tahapan dan mekanisme yang telah ditentukan. Tujuan dari pencatatan warisan budaya nasional itu selain untuk melindungi budaya nasional Indonesia sekaligus untuk menetapkan anggaran pelestarian budaya. Semua warisan budaya nasional dicatat dan diregister agar lebih tertib sekaligus untuk menghindari kasus klaim-klaim budaya nasional oleh negara lain.

Untuk mendapatkan pengakuan dari UNESCO atas situs maupun warisan budaya dunia perlu proses yang cukup panjang, bahkan memerlukan waktu yang lama. Dapat diambil contoh, penghargaan untuk warisan alam berupa lanskap Subak pola pengairan berundak-undak di Bali membutuhkan waktu 12 tahun hingga akhirnya dapat disetujui dalam sidang UNESCO pada Juli 2012.

Meski harus bersusah payah dalam rangka mendapatkan pengakuan UNESCO sebagai situs maupun warisan budaya dunia, dalam beberapa hal banyak keuntungan baik dari sisi prestise maupun bantuan pendanaan dunia

\footnotetext{
${ }^{28}$ http://www.antarabengkulu.com/berita/19359/lestarikan-warisan-budaya-agar-tak-disanksi-unesco, diakses tanggal 9 Juli 2016

29 https://bengkulu.antaranews.com/berita/19359/lestarikan-warisan-budaya-agar-tak-disanksi-unesco, diakses tanggal 27 Mei 2018
} 
meskipun melelaui berbagai ketentuan dan syarat-syarat yang telah ditetapkan oleh UNESCO ${ }^{30}$. Pengakuan UNESCO berarti merupakan pengakuan dunia pula, yang akan meningkatkan citra bangsa Indonesia di mata internasional. Ada apresiasi sekaligus kebanggaan bangsa ketika warisan budaya Indonesia dikenal dunia.

Selain memperoleh pembiayaan dari UNESCO terkait dengan pelestarian warisan budaya tersebut, secara otomatis perhatian dunia internasional akan tertuju kepada Indonesia apabila diketahui terjadi masalah terhadap warisan tersebut. Sebagai contoh, saat terjadi peristiwa gempa di Daerah Istimewa Yogyakarta pada 2 Mei 2006 hingga menimbulkan kerusakan pada Candi Prambanan, salah satu situs yang diakui dunia melalui UNESCO, maka banyak negara menawarkan bantuan baik dalam bentuk biaya perbaikan maupun asistensi tenaga ahli. Inilah yang merupakan dampak positif dengan memasukan kebudayaan Indonesia menjadi warisan dunia melalui World Heritage Centre UNESCO.

Dari analisis mengenai dampak positif dengan didaftarkanya sejumlah kebudayaan Indonesia sebagai warisan budaya tak benda UNESCO tentunya akan berakibat potensi di klaimnya budaya suatu negara menjadi budaya milik bangsa lain, karena tidak mendapatkan pengakuan dari UNESCO sebagai warisan budaya dunia yang berasal dari Indonesia.

Di satu sisi, keuntungan pengakuan terhadap ekspresi budaya tradisional maupun situs Indonesia oleh UNESCO, menimbulkan konsekwensi yang tidak ringan. Konsekwensi tersebut adalah sanggup untuk menjaga, melestarikan dan mewariskan secara estafet kepada generasi berikutnya. Disamping itu, secara berkala, Indonesia harus memberikan laporan ke UNESCO mengenai kondisi keterawatan warisan-warisan tersebut. Apabila Indonesia tidak melaksanakan kewajiban-kewajiban tersebut terhadap situs atau warisan budaya yang telah diakui oleh UNESCO, maka akan dikenai sanksi, yaitu dicabutnya atau

\footnotetext{
${ }^{30}$ Ketika Indonesia sudah meratifikasi salah satu konvensi UNESCO, maka berhak mengajukan usulan kekayaan warisan budaya yang dimiliki Indonesia yang meliputi tiga kategori, warisan situs, warisan alam dan warisan takbenda dan bila salah satu dari usulan tersebut sudah diakui UNESCO maka selanjutnya Indonesia berhak untuk memeroleh biaya pemugaran atau biaya lain yang terkait dengan pelestarian warisan dunia tersebut.
} 
dihapuskan situs atau warisan budaya dunia tersebut dari pengakuan UNESCO. 31

Terhadap warisan takbenda, yang pada umumnya berwujud kebudayaan warisan dunia, agar warisan tersebut tidak mendapatkan sanksi yang sama dari UNESCO terhadap kelalaian-kelalaian dari negara asal, maka salah satu poin penting yang perlu diperhatikan adalah tanggung jawab dalam manajemen pelestarian warisan budaya, apalagi jika sudah ditetapkan menjadi warisan dunia.

Dalam melakukan visi misi UNESCO terutama dalam bidang kebudayaan, Indonesia memiliki Kantor Wakil Republik Indonesia (KWRI) UNESCO yang berkedudukan di Perancis. KWRI UNESCO merupakan kantor perwakilan diplomatik Republik Indonesia di UNESCO yang mempunyai tugas mewakili Indonesia dalam melaksanakan hubungan diplomatik serta memperjuangkan kepentingan nasional Indonesia serta melindungi kepentingan negara dan warga negara Indonesia di UNESCO.

KWRI UNESCO berkedudukan di Paris dan dipimpin oleh Duta Besar/Delegasi Tetap RI untuk UNESCO yang juga Duta Besar RI untuk Perancis. Duta Besar/Delegasi Tetap RI dibantu oleh Duta Besar/Wakil Delegasi Tetap RI untuk UNESCO dan staf pelaksana dan penunjang. ${ }^{32}$

Semestinya pengelolaan warisan budaya tak benda Indonesia menjadi tanggung jawab bersama antara Pemerintah, Pemerintah Daerah, dan seluruh elemen masyarakat, dalam hal perlindungan, pengembangan, pemasaran, investasi dan bisnis, serta pemberdayaan masyarakat. Oleh karena itu pemerintah berkewajiban melakukan perlindungan terhadap hasil karya intelektual dalam bentuk ekspresi budaya tradisional.

\section{Penutup}

Perlindungan terhadap ekspresi budaya tradisional di DIY sangat diperlukan karena berbagai alasan yang mendasarinya yaitu bahwa Yogyakarta memiliki banyak kebudayaan yang beragam jenisnya sehingga terdapat potensi

\footnotetext{
31 Sanksi UNESCO tersebut juga dihadapi Indonesia, yakni salah satu warisan alam dunia di Sumatera, yakni Hutan Hujan Tropis Sumatera. Warisan alam tersebut telah berulang kali direkomendasikan masuk dalam daftar "in danger", namun status itu baru ditetapkan pada pertengahan 2011.

32 http:/ / kwriu.kemdikbud.go.id/tentang-kami/struktur-organisasi/, diakses tanggal 20 November 2016
} 
terhadap klaim kepemilikan dan pemanfaatan terhadap kebudayaan tersebut oleh pihak asing secara ekonomis. Oleh karena itu, diperlukan upaya perlindungan dalam bentuk mekanisme pengaturan dan teknis pelaksanaannya.

Perlindungan berdasarkan Undang-undang Hak Cipta ini belum dapat direalisasikan, karena sejauh ini pemerintah daerah belum mempunyai dokumentasi dan database yang mengkompilasikan budaya lokal masyarakat adatnya. Pemerintah belum melakukan inventarisasi seni dan budaya masyarakat adat secara komprehensif dan integral. Untuk menunjukkan keseriusannya dalam melindungi budaya tradisional masyarakat adat, pemerintah daerah bersama DPRD seharusnya membentuk Rancangan Peraturan Daerah (Raperda) yang memberikan hak cipta atas ekspresi budaya tradisional. Tentunya proses pendokumentasian harus dilakukan dengan menghormati kehendak komunitas lokal apabila tidak ingin budaya masyarakat adat didokumentasikan dengan alasan kerahasiaan dan kesakralan.

Upaya-upaya yuridis tersebut tentunya membutuhkan bukti dan dokumen pendukung yang kuat, dan juga tentunya harus ada komitmen dari negara yang bersangkutan tentang budaya yang dimilikinya tersebut. Sebenarnya konflik tersebut bisa dicegah dengan melakukan strategi pendaftaran budaya Indonesia menjadi warisan budaya dunia ke UNESCO melalui World Heritage Centre. Dengan melakukan pendaftaran budaya-budaya Indonesia menjadi warisan dunia, Indonesia dan para penggiat budaya mendapat keuntungan dengan bantuan dana dan teknis yang diberikan UNESCO untuk pelestarian budaya tersebut.

Bagi pemerintah pusat dan daerah sangat perlu berperan aktif dalam kegiatan identifikasi, inventarisasi, dokumentasi dan registrasi. Peran tersebut perlu dituangkan dalam suatu regulasi dalam pengaturan tentang pengelolaan dan perlindungan kebudayaan di Indonesia. Regulasi tersebut dapat berupa penyempurnaan aturan hak kekayaan intelektual yang telah ada maupun regulasi yang baru yang mengatur secara khusus terhadap perlindungan dan pemanfaatan ekspesi budaya tradisional di Indonesia (suigeneris). 
Sebaiknya regulasi terhadap perlindungan maupun pengelolaan ekspresi budaya tradisional tersebut juga mengedepankan aspek-aspek keadilan bagi masyarakat adat sebagai pemangkunya, dalam bentuk perjanjian benefit sharing antara masyarakat hukum adat dan pihak lain dalam pemanfaatan atas ekspresi budaya tradisional tersebut.

\section{Daftar Pustaka}

\section{Buku}

Badan Penelitian dan Pengembangan HAM Kementerian Hukum dan HAM RI, Perlindungan Kekayaan Intelektual Atas Pengetahuan Tradisional dan Ekpresi Budaya Tradisional Masyarakat Adat, Alumni, Bandung, 2013.

Hadikusuma, Hilman, Pengantar Ilmu Hukum, Mandar Maju, Bandung, 1992.

M. Hadjon Phillipus, Perlindungan Hukum Bagi Rakyat Indonesia, PT. Bina Ilmu, Surabaya, 1987.

Rahardjo, Satjipto, Hukum Dalam Perspektif Sejarah dan Perubahan Sosial, Dalam Pembangunan Hukum Dalam Perspektif Politik Hukum Nasional, Editor Artidjo Alkostar, Rajawali, Jakarta, 1986.

Riswandi, Budi Agus, Syamsudin, Hak Kekayaan Intelektual dan Budaya Hukum, Raja Grafindo Persada, Jakarta, 2005.

Saidin OK, Aspek Hukum Hak Kekayaan Intelektual, Raja Grafindo Persada, Jakarta, 1995.

Sardjono, Agus, Hak Kekayaan Intelektual dan Pengetahuan Tradisional, Alumni, Bandung, 2006. , Membumikan HKI di Indonesia, Nuasa Aulia, Bandung, 2009.

Purba Afrillya,Andrian Krisnawati dan Gazalba Shaleh, TRIP's-WTO dan Hukum HKI Indonesia, Jakarta; Rineka Cipta, 2005.

Thontowi, Jawahir dan Pranoto Iskandar, Hukum Internasional Kontemporer, PT. Refika Aditama, Bandung, 2006.

\section{Hasil Penelitian/Tugas Akhir}

Mauliana, Eriesta, Eksistensi Pendaftaran Ciptaan Ditinjau Dari Undang-undang No. 19 Tahun 2002 tentang Hak Cipta (Studi Kasus Putusan No. 02/HAKI/C/2007/PN Niaga Semarang, Tesis, Program Pasca Sarjana Magister Kenotariatan, Universitas Diponegoro 2010.

\section{Jurnal}

Asri, D. P. B. “Implementasi Pasal 38 ayat (1) Undang-Undang Nomor 28 Tahun 2014 Terhadap Ekspresi Budaya Tradisional Di Kabupaten Sleman", Jurnal Hukum Ius Quia Iustum, Vol. 23 No. 4 Oktober 2016. 
Asri, D. P. B., “Model Kebijakan Strategis Terhadap Pelestarian Kebudayaan Lokal 'Merti Code' Sebagai Aset Daerah Untuk Meningkatkan Sektor Pariwisata Berbasis Budaya", Jurnal Jarlit, 10, 2017.

P. Tololiu, Angelina, "Perlindungan Hukum Terhadap Kain Bentenan Sebagai Ekspresi Budaya Tradisional Sulawesi Utara" Jurnal Hukum Unsrat, Fakultas Hukum Universitas Sam Ratulangi, Vol. II/No. 2/Januari-Maret /2014 Edisi Khusus

Permata, D. "Perlindungan Dan Pengelolaan Budaya Lokal Di Kota Yogyakarta", E-Journal Kajian Hukum, 1(1), Fakultas Hukum Universitas Janabadra, 2016.

Roisah, Kholis, "Perlindungan Ekspresi Budaya Tradiosional Dalam Sistem Hukum Hak Kekayaan Intelektual" Jurnal Masalah-masalah Hukum, Fakultas Hukum Universitas Diponegoro, Jilid 43 Nomor 3, Juli 2014.

\section{Makalah/Pidato}

Antariksa, Basuki, Peluang dan Tantangan Perlindungan Pengetahuan Tradisional dan Ekspresi Budaya Tradisional, Makalah yang disampaikan dalam acara Konsinyering Pencatatan Warisan Budaya Takbenda (WBTB) Indonesia, yang diselenggarakan oleh Direktorat Jenderal Nilai Budaya, Seni dan Film - Kementerian Kebudayaan dan Pariwisata, di Jakarta, tanggal 7 Oktober 2011.

\section{Peraturan Perundang-undangan}

Undang-Undang Nomor 28 tahun 2014 tentang Hak Cipta

Peraturan Daerah Istimewa DI Yogyakarta Nomor 1 Tahun 2013 tentang Kewenangan Dalam Urusan Keistimewaan Daerah Istimewa Yogyakarta

\section{Internet}

https: / / newsplus.antvklik.com/news/kebudayaan-indonesia-diklaimmalaysia/0, diakses tanggal 7 Mei 2018

http:/ / www.pusakaindonesia.org/kekayaan-budaya-indonesia-dan-klaimnegaralain/akses tanggal 28 April 2017

http://kwriu.kemdikbud.go.id/tentang-kami/struktur-organisasi/, diakses tanggal 20 November 2016

http:/ / portal.unesco.org/en/ev.phpURL_ID=13649\&URL_DO=DO_TOPIC\&UR L_SECTION=-471.html, diakses tanggal 20 November 2016

http:/ / www.antarabengkulu.com/berita/19359/lestarikan-warisan-budayaagar-tak-disanksi-unesco, diakses tanggal 9 Juli 2016

https:/ / bengkulu.antaranews.com/berita/19359/lestarikan-warisan-budayaagar-tak-disanksi-unesco, diakses tanggal 27 Mei 2018 
Malaysia Sudah Tujuh Kali Mengklaim Budaya Indonesia, https:/ / nasional.tempo.co/read/411954/malaysia-sudah-tujuh-kalimengklaim-budaya-ri, diakses 27 Mei 2018 